\title{
The Role of CCR5 In HCV InfeCtion
}

\author{
Martin Coenen and Jacob Nattermann \\ Department of Internal Medicine I, University of Bonn, Bonn, Germany
}

\begin{abstract}
Efficient recruitment and activation of immuno-competent cells is crucial for an effective immune response to hepatitis $\mathrm{C}$ virus (HCV) infection. Chemokines and chemokine receptors have been shown to be critically involved in these processes.

The CCR5 chemokine receptor is expressed on several cells of the immune system and has been suggested to influence the susceptibility to HCV infection as well as natural course and progression of hepatitis C. However, these reports are still controversial.

This review will summarize and discuss the available data regarding the potential role of CCR 5 and its ligands in hepatitis C.
\end{abstract}

Key words: chemokine, chemokine receptor, CCR5, $\mathrm{HCV}$, immune response

\section{Chemokines And Chemokine Receptors}

Chemokines, a group of chemotactic cytokines exert chemotactic and immunoregulatory actions [1]. Furthermore, these molecules are involved in modulation of adhesion processes at the endothelium and thus promote the transendothelial migration of leukocytes (haptotaxis). In addition, some chemokines stimulate angiogenesis or angiostasis and thus may play a further role in the suppression of tumor growth or the establishment of an inflammatory response.

Currently, about 50 human chemokines and 20 chemokine receptors have been described. Traditionally, chemokines and chemokine receptors have been classified into four families (CXC, CC, C and CX3C).

Several years ago, a new nomenclature was introduced in which each ligand and each receptor is identified as a member of a sub-family and carries a special number [2]. For example, a chemokine designated CCL5 is a member of the CC sub-family with the number 5. This special chemokine was formerly known as RANTES.

Despite their essential importance for the immune system chemokines and chemokine receptors have been associated with an extraordinary number of diseases [3]. These include autoimmune diseases [4, 5], cancer [5], lung [3], and vascular diseases [6] as well as transplant rejection [7-10].

In addition, the human immunodeficiency virus (HIV) uses different chemokine receptors as co-receptors for entry into the cell [11].

CC chemokines are an important subset of chemokines. They activate specific inflammatory cells such as monocytes or $\mathrm{T}$ lymphocytes and recruit them to the site of inflammation. These CC chemokines bind to specific $G$ protein-coupled receptors, thereby initiating activation and migration of cells.

The CC chemokines CCL3 (MIP-1 $\alpha$ ), CCL4 (MIP$1 \beta$ ), CCL5 (RANTES), and CCL3L1 are the natural ligands of the CC-chemokine receptor CCR5 (CCCKR5, ChemR13 or CMKBR5). The coding sequence for this receptor is located at position 21 on the short arm of chromosome 3 and has a coding sequence of 1056 base pairs, which is translated into a protein of 352 amino acid length.

\section{EXPRESSION OF CHEMOKINE RECEPTORS}

Based on their cytokine profile CD4-positive T-cells can be divided into different subclasses: TH1 cells ( $T$ helper cells type 1) secrete IL-2, IFN- $\gamma$ and lymphotoxin, whereas TH2 cells produce IL-4, IL-5, IL-6, IL-9, IL-10, and IL-13. TH1 cells primarily control the cellular immune response and appear to be involved in chronic inflammatory processes. Th2 cells support the formation of specific antibodies by increasing the B-cell proliferation and their differentiation into plasma cells and play an important role in the development of allergic reactions due to the promotion of IgE production. Interestingly, the expression of specific chemokine receptors is closely associated with the differentiation and activation of specific inflammatory cells. Thus, the CCR 5 receptor is expressed on TH1 lymphocytes [12] but not on TH2 lymphocytes, which primarily express CCR3, and CCR8 and CCR4.

Beyond TH1 cells, CCR 5 has also been detected on monocytes, memory $\mathrm{T}$ cells (CD45RO), stem cells, dendritic cells, microglia, and on a main group of cytotoxic CD8 (+) T lymphocytes.

\section{HCV AND CCR5}

Infiltration of mononuclear inflammatory cells is a central feature of hepatitis $\mathrm{C}$ virus (HCV) infection. Here, many of the liver-infiltrating cells express high levels of the CCR5 receptor. Moreover, high levels of the chemokines CCL3, CCL4 and CCL5 can be found in the HCV-infected liver [13].

In vitro data suggest that the hepatitis $C$ virus can directly influence the secretion of these chemokines. For instance, it could be shown that binding of the HCV E2 envelope protein to the tetraspanin CD81, which serves as a co-receptor for $\mathrm{HCV}$, induces release 
of the CCR 5 ligand CCL5 by CD8 (+) T cells [14]. In addition, the HCV core and NS5A proteins have been demonstrated to affect CCL5 secretion by modulating CCL5 promoter activity [15].

Of note, CCR5 has been shown to promote hepatic fibrosis in mice and marked up-regulation of CCL5 and CCR 5 has been found in patients with hepatic cirrhosis, confirming activation of the CC chemokine system in human fibrogenesis $[16,17]$.

In contrast to the infected liver significantly reduced numbers of CCR5-expressing lymphocytes can be found in the peripheral blood of HCV-infected patients. This may be due to HCV-induced intrahepatic chemokine secretion mediating the hepatic recruitment of CCR5-mediated hepatic (+) T-cell and thus reflect altered compartmentalization of CCR $5(+)$ lymphocytes.

A strong anti-viral type 1 immune response has been shown to be associated with a successful elimination of the virus, both during the acute phase of infection and an antiviral therapy [18-20]. This would suggest that accumulation of CCR5 (+) TH1 cells in the HCV-infected liver contributes to an effective antiviral immune response. However, these relationships appear to be more complex. We recently showed that CCR5 (+) lymphocytes are characterized by a high expression of the inhibitory NK cell receptor NKG2A [21]. Therefore, these cells are very sensitive to NKG2A-mediated inhibition of cytotoxic function. As hepatitis $\mathrm{C}$ is associated with a high intrahepatic expression of the NKG2A ligand HLA-E, intra-hepatic accumulation of CCR5(+)NKG2A(+) lymphocytes could interfere with an effective immune response. In addition, CCR5 $(+)$ $\mathrm{T}$ cells may have a role in immune-mediated liver cell damage during chronic hepatitis C [22].

\section{The CCR5 32 Polymorphism}

The CCR5 gene is subject to various mutations, including a deletion of 32 base pairs. This mutation, called CCR $5 \Delta 32$, leads to a shift in the reading frame, resulting in the formation of a truncated, non-functional protein, which is not expressed on the cell surface $[23,24]$. In a Caucasian population the CCR $5 \Delta 32$ allele frequency is about $10-20 \%$ [23].

The frequency of the CCR $5 \Delta 32$-polymorphism decreases from Northern to Southern Europe. Moreover, the $\Delta 32$ allele is absent in African and Asian cohorts. Thus, it is believed that this mutation first occurred in Northern Europe not so long ago.

Individuals who are homozygous for the mutation and thus "genetically negative" for CCR5, develop normal and are healthy. The same was observed in CCR 5 knockout mice. Therefore, it was originally presumed that the CCR5 receptor has no relevant importance to the immune system. In further studies, however, it could be shown that lack of CCR5 is associated with a significantly altered immune response in mice. For example, infection with Cryptpcoccus neoformans is often fatal in CCR5-deficient mice, whereas wild-type mice survive. Furthermore, experiments using CCR 5 knockout demonstrated that lack of CCR5 is associated with an increased $\mathrm{T}$-cell immune response in various infectious diseases [25-27].
Even in non-infectious inflammatory reactions CCR5 seems to play an important role in the regulation of T-cell functions. Recently, it has been reported that CCR5-deficient mice, in which a $\mathrm{T}$ cell-mediated autoimmune hepatitis had been induced, displayed a significantly greater liver damage in comparison to CCR5-positive mice [28].

Studies on the clinical relevance of CCR $5 \Delta 32$ mutation in humans indicated that absence of the CCR 5 receptor may, under certain circumstances, have either a positive or a negative effect. Patients carrying a homozygous CCR $5 \Delta 32$-genotype have a higher risk of death during infection with West Nile virus [29]. On the other hand, it is presumed that the absence of CCR5 confers some protection against infection with smallpox (or the plague), which is reflected by the relatively high prevalence of this mutation in Central and Northern Europe.

Moreover, CCR 5 has been suggested to play a role in transplant rejection [7-10, 30]. For instance, a prospective, biopsy-controlled study suggested that the local expression of the CCR5-ligand RANTES (CCL5) leads to the directional movement of activated CCR 5 bearing $T$ cells into the renal allograft thereby mediating acute rejection [10]. Fischrieder et al. reported patients homozygous for CCR $5 \Delta 32$ to show longer survival of renal transplants than those with other genotypes [9]. In contrast, Bickerstaff and coworkers found rapid rejection of renal allografts in CCR5-/- mice with many histopathologic features observed during AHR of human renal allografts [8]. Thus, the exact role of CCR5/CCR5 polymorhpisms in renal transplantation remains controversial [30].

\section{HCV AND CCR $5 \Delta 32$}

With respect to HCV infection data regarding the importance of CCR5 $\Delta 32$ mutation are conflicting. Woitas et al. reported that patients with chronic $\mathrm{HCV}$ infection were significantly more likely to exhibit the homozygous CCR5- $\Delta 32 / C C R 5-\Delta 32$ genotype compared to a healthy control group. Moreover, CCR5$\Delta 32$ homozygosity in this study was associated with significantly increased HCV viral loads and CD8+ T lymphocyte counts in the peripheral blood [31]. Thus, the results of this study would suggest that individuals with a CCR $5 \Delta 32 /$ CCR $5 \Delta 32$ genotype display an increased susceptibility to HCV infection.

However, in subsequent studies this association could not be confirmed. In this regard, it has been speculated that increased CCR $5 \Delta 32$-frequency may be a specific characteristic of haemophilic patients with chronic hepatitis C but without HIV infection - and rather reflects resistance to HIV-1 than increased susceptibility to HCV. However, a detailed statistical analysis showed that the high frequency of CCR $5 \Delta 32$ in chronic hepatitis $\mathrm{C}$ reported by Woitas et al. could not be explained by the HIV-mediated selection pressure alone [32].

Alternatively, the strategy of patient selection in the Woitas study (haemophilia versus chronic liver disease) or the analysis of heterogeneous cohorts (stage and duration of infection, infecting HCV genotype, demographic factors) might explain these discrepant results. 
This was examined in two independent largely homogeneous cohorts of $\mathrm{HCV}$-infected women with a known source of infection. In the late $70 \mathrm{~s}$ these women were infected by anti-D immunoglobulin contaminated with hepatitis $\mathrm{C}$ virus (HCV) genotype $1 \mathrm{~b}$ from a single erythrocyte donor administered for prophylaxis of rhesus isoimmunization throughout East Germany and Ireland, respectively. In contrast to the data published by Woitas and co-workers the CCR $5 \Delta 32$ mutation was associated with spontaneous elimination of the virus in the Irish anti-D cohort [33]. However, in the Eastern German "Anti-D cohort," we found carriers of the CCR $5 \Delta 32$ polymorphism to be significantly more likely to develop chronic infection than women with a homogeneous wild-type genotype (Nattermann et al., AASLD 2009).

Similar discrepant results have been published regarding a possible association between the CCR $5 \Delta 32$ polymorphism and the degree of the HCV-associated hepatitis. Data obtained in the Irish "Anti-D cohort" [33] and in two other studies [34, 35] showed a less pronounced hepatic inflammation in carriers of the CCR5 $\Delta 32$ mutation as compared to patients with a homozygous wild type. However, these results could not be confirmed in other publications [36-38].

In contrast to these controversial data, it is widely accepted that the CCR $5 \Delta 32$ mutation does not affect response to standard combination therapy with pegylated interferon and ribavirin. Although the CCR5 $\Delta 32$ polymorphism was associated with a significantly poorer response to monotherapy with standard interferon [39], no study could confirm a similar effect for patients treated with pegylated interferon in combination with ribavirin $[32,39,40]$.

Recently, Dolan et al. published a very elgant and comprehensive study which might provide some explanations regarding the controversial data on the role of CCR5 in hepatitis $\mathrm{C}$ as this work shed light on the complexity of such associations [41]. In this study different cohorts of HIV-positive and HIV-negative persons were analyzed with regard to polymorphisms in the CCR5 gene and the gene of the CCR5 ligand CCL3L1. CCR5 is an important co-receptor for HIV and earlier studies demonstrated that the CCR5D32 mutation blocks infection of CD4 lymphocytes. Dolan et al. identified another mechanism by which CCR 5 in association with its ligands affect the course of HIV infection.

In this work the study subjects were classified into three 'genetic risk groups' (GRGs) based on variation in CCR5-CCL3L1 genotypes that are associated with risk of acquiring HIV infection and on HIV replication.

Interestingly the authors could show a direct association of these GRKs with the cell-mediated immune response. As a marker they determined the delayedtype immune response (type IV), which is a common 'readout' of cellular immunity. This immune reaction is based on activation of TH1 lymphocytes induced by a soluble antigen which in turn results in activation of macrophages. A typical example is the tuberculine test which induces an immune reaction of pre-sensitized T-lymphocytes after inoculation of tuberculine into the skin. Dolan and co-workers showed an increased
type-IV immune response in those GRGs associated with a delayed disease progression.

Thus, the authors concluded that CCR5 and its ligands not only interfere with viral entry of HIV into the cell but also affect anti-viral responses via modulating cellular immunity.

The complexity of these associations was further emphasized by the observation that the CCR 5 haplotype $\left(\mathrm{HHG}^{*} 2\right)$ comprising the $\Delta 32$-mutation (both homozygous or in combination with another specific haplotype $(\mathrm{HHE})$ ) is a predictor of a weak cell-mediated immune response and a rapid progression of HIV infection. However, the same CCR $5 \mathrm{HHG}^{*} 2$ haplotype in combination with the CCR5 HHC haplotype was associated with a slower progression of infection and possibly with a stronger immune response.

Similar complex relationships could also play a role in HCV infection. For instance, variations of the CCL3L1 gene have recently been shown to affect $\mathrm{HCV}$ infection [42]. Moreover, Ahlenstiehl et al. could show a significantly decreased HCV-specific IFN- $\gamma$ response of $\mathrm{CD} 8(+)$ T-cells in carriers of the CCR $5 \Delta 32$ allele as compared to cells from patients with a homozygeous wildtype genotype. This finding suggests the CCR $5 \Delta 32$ polymorphisms to possibly affect cellular immune responses in HCV infection [43].

In summary there is clear evidence for a critical role of the CCR5 receptor and its' ligands for the regulation of immune response which might also play a role in HCV infection. However, further studies with larger number of patients and a more detailed genetic analysis are necessary to precisely define the role of CCR 5 in HCV infection.

Conflict of interest: The authors have no commercial or other association that might pose a conflict of interest.

Financial support: This work was supported by the H. W. and J. Hector Foundation [grant number M42].

\section{REFERENCES}

1. Mackay CR. Chemokines: immunology's high impact factors. Nat Immunol 2001;2:95-101.

2. Murphy PM, Baggiolini M, Charo IF, Hebert CA, Horuk $\mathrm{R}$, Matsushima K, Miller LH, et al. International union of pharmacology. XXII. Nomenclature for chemokine receptors. Pharmacol Rev 2000;52:145-176.

3. Gerard C, Rollins BJ. Chemokines and disease. Nat Immunol 2001;2:108-115.

4. Kunkel SL, Godessart N. Chemokines in autoimmunity: from pathology to therapeutics. Autoimmun Rev 2002;1: 313-320.

5. Balkwill F. Cancer and the chemokine network. Nat Rev Cancer 2004;4:540-550.

6. Charo IF, Taubman MB. Chemokines in the pathogenesis of vascular disease. Circ Res 2004;95:858-866.

7. Abdi R, Tran TB, Sahagun-Ruiz A, Murphy PM, Brenner BM, Milford EL, McDermott DH. Chemokine receptor polymorphism and risk of acute rejection in human renal transplantation. J Am Soc Nephrol 2002;13:754-758.

8. Bickerstaff A, Nozaki T, Wang JJ, Pelletier R, Hadley G, Nadasdy G, Nadasdy T, et al. Acute humoral rejection of renal allografts in CCR5(-/-) recipients. Am J Transplant 2008;8:557-566.

9. Fischereder M, Luckow B, Hocher B, Wuthrich RP, Rothenpieler U, Schneeberger H, Panzer U, et al. CC 
chemokine receptor 5 and renal-transplant survival. Lancet 2001;357:1758-1761.

10. Panzer U, Reinking RR, Steinmetz OM, Zahner G, Sudbeck U, Fehr S, Pfalzer B, et al. CXCR3 and CCR5 positive T-cell recruitment in acute human renal allograft rejection. Transplantation 2004;78:1341-1350.

11. Lusso P. HIV and the chemokine system: 10 years later. EMBO J 2006;25:447-456. Epub 2006 Jan 2026.

12. Loetscher $\mathrm{P}$, Uguccioni M, Bordoli L, Baggiolini M, Moser B, Chizzolini C, Dayer JM. CCR5 is characteristic of Th1 lymphocytes. Nature 1998;391:344-345.

13. Shields PL, Morland CM, Salmon M, Qin S, Hubscher SG, Adams DH. Chemokine and chemokine receptor interactions provide a mechanism for selective $\mathrm{T}$ cell recruitment to specific liver compartments within hepatitis C-infected liver. J Immunol 1999;163:6236-6243.

14. Nattermann J, Zimmermann H, Iwan A, von LilienfeldToal M, Leifeld L, Nischalke HD, Langhans B, et al. Hepatitis $\mathrm{C}$ virus $\mathrm{E} 2$ and $\mathrm{CD} 81$ interaction may be associated with altered trafficking of dendritic cells in chronic hepatitis C. Hepatology 2006;44:945-954.

15. Soo HM, Garzino-Demo A, Hong W, Tan YH, Tan YJ, Goh PY, Lim SG, et al. Expression of a full-length hepatitis $\mathrm{C}$ virus cDNA up-regulates the expression of $\mathrm{CC}$ chemokines MCP-1 and RANTES. Virology 2002;303: 253-277.

16. Seki E, De Minicis S, Gwak GY, Kluwe J, Inokuchi S, Bursill CA, Llovet JM, et al. CCR1 and CCR5 promote hepatic fibrosis in mice. J Clin Invest 2009;119:18581870.

17. Schwabe RF, Bataller R, Brenner DA. Human hepatic stellate cells express CCR5 and RANTES to induce proliferation and migration. Am J Physiol Gastrointest Liver Physiol 2003;285:G949-958.

18. Missale G, Bertoni R, Lamonaca V, Valli A, Massari M, Mori C, Rumi MG, et al. Different clinical behaviors of acute hepatitis $\mathrm{C}$ virus infection are associated with different vigor of the anti-viral cell-mediated immune response. J Clin Invest 1996;98:706-714.

19. Cramp ME, Rossol S, Chokshi S, Carucci P, Williams R, Naoumov NV. Hepatitis C virus-specific T-cell reactivity during interferon and ribavirin treatment in chronic hepatitis C. Gastroenterology 2000;118:346-355.

20. Schulze Zur Wiesch J, Pieper D, Stahmer I, Eiermann T, Buggisch P, Lohse A, Hauber J, et al. Sustained virological response after early antiviral treatment of acute hepatitis C virus and HIV coinfection. Clin Infect Dis 2009; 49:466-472.

21. Nattermann J, Sherzada R, Iwan A, Bogen D, Niederle IM, Schulte D, Mertens E, et al. Hepatitis C virus-induced secretion of inflammatory chemokines preferentially recruits NKG2A $+\mathrm{CD} 8+\mathrm{T}$ cells. J Infect Dis 2008; 198:213-217.

22. Apolinario A, Majano PL, Alvarez-Perez E, Saez A, Lozano C, Vargas J, Garcia-Monzon C. Increased expression of $\mathrm{T}$ cell chemokines and their receptors in chronic hepatitis C: relationship with the histological activity of liver disease. Am J Gastroenterol 2002;97:2861-2870.

23. Dean M, Carrington M, Winkler C, Huttley GA, Smith MW, Allikmets R, Goedert JJ, et al. Genetic restriction of HIV-1 infection and progression to AIDS by a deletion allele of the CKR5 structural gene. Hemophilia Growth and Development Study, Multicenter AIDS Cohort Study, Multicenter Hemophilia Cohort Study, San Francisco City Cohort, ALIVE Study. Science 1996;273:18561862.

24. Liu R, Paxton WA, Choe S, Ceradini D, Martin SR, Horuk R, MacDonald ME, et al. Homozygous defect in HIV-1 coreceptor accounts for resistance of some multiply-exposed individuals to HIV-1 infection. Cell 1996; 86:367-377.
25. Zhou Y, Kurihara T, Ryseck RP, Yang Y, Ryan C, Loy J, Warr $G$, et al. Impaired macrophage function and enhanced $\mathrm{T}$ cell-dependent immune response in mice lacking CCR5, the mouse homologue of the major HIV-1 coreceptor. J Immunol 1998;160:4018-4025.

26. Nansen A, Christensen JP, Andreasen SO, Bartholdy C, Christensen JE, Thomsen AR. The role of CC chemokine receptor 5 in antiviral immunity. Blood 2002;99:12371245 .

27. Algood HM, Flynn JL. CCR5-deficient mice control Mycobacterium tuberculosis infection despite increased pulmonary lymphocytic infiltration. J Immunol 2004;173: 3287-3296.

28. Moreno C, Gustot T, Nicaise C, Quertinmont E, Nagy N, Parmentier M, Le Moine O, et al. CCR5 deficiency exacerbates T-cell-mediated hepatitis in mice. Hepatology 2005;42:854-862.

29. Glass WG, McDermott DH, Lim JK, Lekhong S, Yu SF, Frank WA, Pape J, et al. CCR5 deficiency increases risk of symptomatic West Nile virus infection. J Exp Med 2006;203:35-40.

30. Brabcova I, Petrasek J, Hribova P, Hyklova K, Bartosova K, Lacha J, Viklicky O. Genetic variability of major inflammatory mediators has no impact on the outcome of kidney transplantation. Transplantation 2007;84:10371044.

31. Woitas RP, Ahlenstiel G, Iwan A, Rockstroh JK, Brackmann HH, Kupfer B, Matz B, et al. Frequency of the HIV-protective CC chemokine receptor 5-Delta32/ Delta32 genotype is increased in hepatitis C. Gastroenterology 2002;122:1721-1728.

32. Ahlenstiel G, Woitas RP, Rockstroh J, Spengler U. CCchemokine receptor 5 (CCR5) in hepatitis C--at the crossroads of the antiviral immune response? J Antimicrob Chemother 2004;53:895-898.

33. Goulding C, McManus R, Murphy A, MacDonald G, Barrett S, Crowe J, Hegarty J, et al. The CCR5-delta32 mutation: impact on disease outcome in individuals with hepatitis C infection from a single source. Gut 2005;54: 1157-1161.

34. Wald O, Pappo O, Ari ZB, Azzaria E, Wiess ID, Gafnovitch I, Wald $\mathrm{H}$, et al. The CCR5Delta32 allele is associated with reduced liver inflammation in hepatitis C virus infection. Eur J Immunogenet 2004;31:249-252.

35. Hellier S, Frodsham AJ, Hennig BJ, Klenerman P, Knapp S, Ramaley P, Satsangi J, et al. Association of genetic variants of the chemokine receptor CCR5 and its ligands, RANTES and MCP-2, with outcome of HCV infection. Hepatology 2003;38:1468-1476.

36. Goyal A, Suneetha PV, Kumar GT, Shukla DK, Arora N, Sarin SK. CCR5Delta32 mutation does not influence the susceptibility to HCV infection, severity of liver disease and response to therapy in patients with chronic hepatitis C. World J Gastroenterol 2006;12:4721-4726.

37. Ruiz-Ferrer M, Barroso N, Antinolo G, Aguilar-Reina J. Analysis of CCR5-Delta 32 and CCR2-V64I polymorphisms in a cohort of Spanish HCV patients using realtime polymerase chain reaction and fluorescence resonance energy transfer technologies. J Viral Hepat 2004; 11:319-323.

38. Wasmuth HE, Werth A, Mueller T, Berg T, Dietrich CG, Geier A, Schirin-Sokhan R, et al. CC chemokine receptor 5 delta32 polymorphism in two independent cohorts of hepatitis $C$ virus infected patients without hemophilia. J Mol Med 2004;82:64-69.

39. Ahlenstiel G, Berg T, Woitas RP, Grunhage F, Iwan A, Hess L, Brackmann HH, et al. Effects of the CCR5-Delta 32 mutation on antiviral treatment in chronic hepatitis C. Journal of Hepatology 2003;39:245-252.

40. Glas J, Torok HP, Simperl C, Konig A, Martin K, Schmidt F, Schaefer M, et al. The Delta 32 mutation of 
the chemokine-receptor 5 gene neither is correlated with chronic hepatitis $\mathrm{C}$ nor does it predict response to therapy with interferon-alpha and ribavirin. Clin Immunol 2003;108:46-50

41. Dolan MJ, Kulkarni H, Camargo JF, He W, Smith A, Anaya JM, Miura T, et al. CCL3L1 and CCR5 influence cell-mediated immunity and affect HIV-AIDS pathogenesis via viral entry-independent mechanisms. Nat Immunol 2007;8:1324-1336.

42. Grunhage F, Nattermann J, Gressner OA, Wasmuth HE, Hellerbrand C, Sauerbruch T, Spengler U, et al. Lower copy numbers of the chemokine CCL3L1 gene in patients with chronic hepatitis C. J Hepatol;52:153-159.

43. Ahlenstiel G, Woitas RP, Iwan A, Nattermann J, Feldmann G, Rockstroh JK, Oldenburg J, et al. Effects of the CCR5-Delta32 mutation on hepatitis $C$ virus-specific immune responses in patients with haemophilia. Immunol Invest 2009;38:1-13.
Received: February 12, 2010 / Accepted: March 12, 2010

Address for correspondence:

J. Nattermann, MD

Department of Internal Medicine I

University of Bonn

Sigmund-Freud-Straße 25

53105 Bonn

Germany

Tel: $\quad+49-228-287-51416$

Fax: +49-228-287-51419

E-mail: jacob.nattermann@ukb.uni-bonn.de 